\title{
Regulation of pectin methylesterase and polygalacturonate lyase activity during differentiation of infection structures in Uromyces viciae-fabae
}

\author{
Holger Deising, Alexander K. Frittrang, Stefan Kunz and Kurt Mendgen
}

Author for correspondence: Holger Deising. Tel: +49 7531 882356. Fax: +49 7531883035.

Universităt Konstanz, Fakultăt für Biologie, Lehrstuhl für

Phytopathologie,

Universitatsstrasse 10

D-78434 Konstanz, Germany
The broad bean rust fungus Uromyces viciae-fabae differentiates infection structures up to the haustorial mother cell stage on thigmotropically inductive membranes in the absence of its host plant. Formation of pectin methylesterase (PME) and polygalacturonate lyase (PL), potentially involved in host cell wall degradation, was studied during infection structure differentiation by this biotrophic fungus. PME was first detectable when substomatal vesicles were formed and reached a maximum when infection hyphae and haustorial mother cells were differentiated. Four isoenzymes, exhibiting pls of $8.2,5.6,5.2$ and 4.5 , were separated by chromatofocusing, and the kinetics of their synthesis and the $K_{\mathrm{m}} \mathrm{s}$ of the three major isoenzymes were determined. The enzyme activity was formed independently of the presence of its substrate and its regulation was thus differentiation-specific. A single PL was induced when haustorial mother cells were formed and its synthesis appeared to be controlled by both the developmental stage of infection structures and the availability of its substrate. Polygalacturonate concentrations lower than $0.025 \mathrm{mg} \mathrm{ml}^{-1}$ induced enzyme synthesis, and at $0.25 \mathrm{mg} \mathrm{ml}^{-1}$ the induction process appeared to be saturated. Enzyme formation in the presence of $50 \mathrm{mM}$ glucose, fructose or sucrose suggested that neither pectic enzyme was subject to catabolite repression. Significant proportions of PME (approx. 57\%) and PL (approx. 76\%) activity were located extracellularly in 24-h-old differentiated infection structures and could contribute to the establishment of the parasite. Physico-chemical and kinetic properties of the enzymes and associated alterations of the apoplastic pH of infected host plants appeared to be important factors in the success of infection and could explain the restriction of cell wall damage at the penetration site usually observed in interactions involving obligately biotrophic fungi.

Keywords: Uromyces viciae-fabae, cell-wall-degrading enzymes, differentiation specificity, infection structures, obligate biotrophy

\section{INTRODUCTION}

Cell-wall-degrading enzymes are thought to be of critical importance in the success of fungal plant pathogens (Cooper, 1984; Keon et al., 1987). However, while in some host-pathogen interactions these enzymes are thought to be determinants of virulence (Köller et al.,

Abbreviations : IWF, intercellular washing fluid; p.i., post-inoculation; PL, polygalacturonate lyase; PME, pectin methylesterase.
1982; Crawford \& Kolattukudy, 1987; Cotty et al., 1990; Wattad et al., 1994), this issue has been disputed in other systems (Keen \& Erwin, 1971; Howell, 1976; Cooper \& Durrands, 1989; Scott-Craig et al., 1990). Fungal pathogens differ with respect to host cell wall degradation and tissue maceration, and these differences are particularly evident when different groups of fungi, for example necrotrophs on the one hand and obligate biotrophs on the other, are compared (Cooper, 1984). Necrotrophs and saprophytes synthesize and secrete large quantities of cell- 
wall-degrading enzymes and have been extensively studied with respect to the regulation of these enzymes, with special emphasis given to pectic enzymes. In general, the presence of substrate results in enzyme induction. In contrast, low-molecular-mass carbon sources, such as mono- and disaccharides, function as repressors of enzyme induction (Crawford \& Kolattukudy, 1987; Dean \& Timberlake, 1989; Wattad et al., 1994; H. Deising, E. Rodriguez-Galvez \& K. Mendgen, unpublished data). This type of regulation results in the formation of large quantities of enzymes in the host and extensive tissue maceration (Cooper, 1983).

In contrast, obligately biotrophic fungi such as rusts and powdery mildews cause minimal damage to the cell walls of their host plant, and this has raised the question of whether these fungi are capable of producing 'true' walldegrading enzymes (see review by Mendgen \& Deising, 1993). In uredospores and germlings of Uromyces viciaefabae which had differentiated appressoria, cellulases and 'true' pectic enzymes were not detectable (Cooper, 1984; Keon et al., 1987), and the authors speculated that this biotroph penetrates plant cell walls by means of glycanases and glycosidases which degrade neutral wall polymers.

However, if cell-wall-degrading enzymes were synthesized only after the fungus had invaded the leaf mesophyll, experiments performed with spores, germ tubes or appressoria would not allow their detection. Therefore, membranes providing a thigmotropic signal that causes differentiation of rust infection structures, including infection hyphae and haustorial mother cells (Deising et al., 1991), have been used to analyse enzyme formation in relation to morphogenesis. Using the same approach, Heiler et al. (1993) showed that in U. viciae-fabae formation of cellulases begins when appressoria are differentiated. Frittrang et al. (1992) reported the partial purification and characterization of pectin methylesterases (PMEs) which, like cellulases of this fungus, are formed in a strictly differentiation-specific and substrate-independent manner.

In this paper we show that, in addition to PME, U. viciaefabae produces a polygalacturonate lyase (PL). While the formation of both enzymes requires fungal morphogenesis, induction of PL occurs only in the presence of its substrate. Neither enzyme is subject to catabolite repression and significant quantities of both are secreted during infection structure differentiation. The kinetics of synthesis and physico-chemical properties of these pectic enzymes, and the associated changes in the apoplastic $\mathrm{pH}$ of infected plants are discussed with respect to highly localized wall degradation by rust fungi.

\section{METHODS}

Fungal culture and production of infection structures. Uredospores of U. viciae-fabae isolate I2 were propagated on Vicia faba cv. Con Amore (Deising et al., 1991). Spores were either used directly after harvesting or stored at $-70{ }^{\circ} \mathrm{C}$ until needed.

Infection structure differentiation was induced by thigmotropic stimuli provided by scratched polyethylene membranes as described previously (Deising et al., 1991). Non-differentiated germlings were obtained $4 \mathrm{~h}$ post-inoculation (p.i.) from noninducing substrates (membranes that had not been scratched). Each membrane $\left(1870 \mathrm{~cm}^{2}\right)$ was inoculated with $170 \mathrm{mg}$ uredospores. Since PME activity is tightly controlled by fungal morphogenesis and not by the presence of substrate, membranes were sprayed with $4 \mathrm{ml}$ of sterile distilled $\mathrm{H}_{2} \mathrm{O}$ after inoculation. They were subsequently incubated at $19{ }^{\circ} \mathrm{C}$ and $100 \%$ relative humidity. To induce PL, membranes were routinely sprayed with $4 \mathrm{ml}$ sterile aqueous sodium polygalacturonate $\left(1 \mathrm{mg} \mathrm{ml}^{-\mathbf{1}}\right)$ (Sigma). To determine the dependence of enzyme induction on substrate concentration, sodium polygalacturonate concentrations ranging from 0 to $1 \mathrm{mg} \mathrm{ml}^{-1}$ were applied. In order to analyse whether pectic enzymes of the broad bean rust fungus are catabolite-repressible, mono- and disaccharides were applied as $50 \mathrm{mM}$ solutions either alone (PME) or in combination with $1 \mathrm{mg} \mathrm{ml}^{-1}$ sodium polygalacturonate (PL). The $\mathrm{pH}$ of the solutions used for PL induction was adjusted to $5 \cdot 4$. To relate the pattern of expression of enzyme activities to different stages of fungal morphogenesis, structures were harvested at different times after inoculation of membranes. These time points were based on the kinetics of infection structure differentiation as published previously (Deising et al., 1991).

To demonstrate the fungal origin of PL, cycloheximide was applied at $0 \cdot 1$ or $10 \mu \mathrm{g} \mathrm{ml}^{-1}$ to uredosporelings $8 \mathrm{~h}$ after inoculation and substrate application, and streptomycin sulfate or ampicillin $\left(0.5 \mathrm{mg} \mathrm{ml}^{-1}\right.$ of each in combination with $0.1 \%$ polygalacturonate) (Melgarejo et al., 1985; Heiler et al., 1993) were applied directly to inoculated membranes. Cycloheximide and ampicillin were obtained from Sigma, and streptomycin sulfate from Serva.

Enzyme extraction and assay conditions. PME was extracted and assayed as described previously (Frittrang et al., 1992), with minor modifications. Briefly, spores, germ tubes and infection structures were homogenized in $50 \mathrm{mM}$ Tris $/ \mathrm{HCl}$ buffer, $\mathrm{pH} 8 \cdot 0$, containing $150 \mathrm{mM} \mathrm{NaCl}$. Homogenization of dormant uredospores was carried out using a pestle and mortar. A PotterElvehjem homogenizer (Kummer) was used to homogenize all other structures. Homogenization was carried out at $2-4{ }^{\circ} \mathrm{C}$. The homogenate was centrifuged $\left(24000 \mathrm{~g}, 20 \mathrm{~min}, 2^{\circ} \mathrm{C}\right)$ and the clear supernatant was subjected to $\left(\mathrm{NH}_{4}\right)_{2} \mathrm{SO}_{4}$ precipitation (degree of saturation 0.8 ) and centrifuged as described above. The pellet was resuspended in $25 \mathrm{mM}$ Tris/ $\mathrm{HCl}, \mathrm{pH} 8 \cdot 0$, dialysed against 500 vols of the same buffer overnight, centrifuged $\left(20000 \mathrm{~g}, 30 \mathrm{~min}, 2^{\circ} \mathrm{C}\right)$, and the supernatant stored at $-70^{\circ} \mathrm{C}$ or used directly to determine PME activity.

The assay mixture, if not otherwise stated, consisted of $16 \mathrm{mg} \mathrm{ml}^{-1}$ apple pectin type $B$ (degree of esterification $72-79 \%$ ) and $150 \mathrm{mM} \mathrm{NaCl}$ in $5 \mathrm{mM}$ PIPES buffer, $\mathrm{pH} 7 \cdot 0$. For substrate specificity analyses, other apple pectins (type A1, degree of esterification 35-40\%; type A2, degree of esterification $\sim 65 \%$ ) and pectin type $N$ (degree of esterification $\sim 8 \%$ ) (all from Roth) were used at a final concentration of $3.2 \%(\mathrm{w} / \mathrm{v})$ in the buffer described above. Enzyme activity was determined $\mathrm{pH}$-metrically at $30^{\circ} \mathrm{C}$ (Frittrang et al., 1992).

For extraction of PL, homogenization was carried out in $50 \mathrm{mM}$ Tris/ $\mathrm{HCl}$ buffer, $\mathrm{pH} 8.5$, containing $1 \mathrm{mM} \mathrm{PMSF}$ and $1 \%(\mathrm{v} / \mathrm{v})$ methanol. The homogenate was adjusted to contain $500 \mathrm{mM}$ $\mathrm{NaCl}$, and after centrifugation $(45000 \mathrm{~g}, 20 \mathrm{~min})$ the supernatant was subjected to $\left(\mathrm{NH}_{4}\right)_{2} \mathrm{SO}_{4}$ precipitation (degree of saturation $0.9)$. After centrifugation $(45000 \mathrm{~g}, 20 \mathrm{~min})$, the pellet was dissolved in $10 \mathrm{mM}$ Tris $/ \mathrm{HCl}$ buffer, $\mathrm{pH} 9.5$, and dialysed against 500 vols $1 \mathrm{mM}$ Tris $/ \mathrm{HCl}, \mathrm{pH} 9 \cdot 5$, overnight. Protein precipitates were removed by centrifugation as described above, 
and the supernatant was used for PL assay and protein determination. All operations were performed at $2-4{ }^{\circ} \mathrm{C}$.

The PL assay mixture consisted of (final concentrations) $5 \mathrm{mg}$ polygalacturonate $\mathrm{ml}^{-1}$ and $1.41 \mathrm{mM} \mathrm{CaCl}_{2}$ in $100 \mathrm{mM}$ 2-amino-

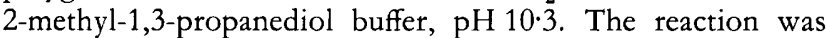
carried out at $30^{\circ} \mathrm{C}$, and the increase in $A_{235}$ was used as a measure of enzyme activity. Controls contained either equal amounts of heat-inactivated enzyme, or active enzyme plus EDTA at a final concentration of $5 \mathrm{mM}$.

\section{Column chromatography}

lon exchange chromatography. To separate PME isoforms A and $\mathrm{B}$, ion exchange chromatography was performed on a polybuffer exchanger (PBE) 94 (Pharmacia). The column (gel bed $9 \mathrm{ml}$, $18 \mathrm{~cm}$ long) was equilibrated with $25 \mathrm{mM}$ Tris $/ \mathrm{HCl}, \mathrm{pH} 8 \cdot 0$. Crude extract $(15 \mathrm{ml})$ containing a maximum of $470 \mathrm{mg}$ protein was dialysed against equilibration buffer overnight and applied to the column. After collecting the unbound fraction containing PME isoform $A$ and extensive washing with equilibration buffer (10 column vols), PME isoforms $B$ and $C$ were eluted with $1 \mathrm{M}$ $\mathrm{NaCl}$. The flow rate was $0.25 \mathrm{ml} \mathrm{min}^{-1}$. Bound and unbound fractions were $\left(\mathrm{NH}_{4}\right)_{2} \mathrm{SO}_{4}$-precipitated and dialysed against the respective equilibration buffer used in chromatofocusing. All operations were carried out at $4{ }^{\circ} \mathrm{C}$.

\section{Chromatofocusing}

Chromatofocusing was performed on a PBE94 column (Pharmacia) (gel bed $9 \mathrm{ml}, 18 \mathrm{~cm}$ long). For chromatofocusing in the $\mathrm{pH}$ range $9 \cdot 0-7 \cdot 0$, the column was equilibrated with $25 \mathrm{mM}$ ethanolamine, $\mathrm{pH} 9 \cdot 0$. Unbound fractions from ion exchange chromatography columns (containing PME isoform A), dialysed against 100 vols equilibration buffer, was applied to the column, and $5 \mathrm{ml}$ equilibration buffer was subsequently loaded. Proteins with pIs in the range $9 \cdot 0-7.5$ were eluted with $10 \%$ (v/v) polybuffer PB 96 (Pharmacia), adjusted to $\mathrm{pH} 7 \cdot 0$. The column was then washed with $1 \mathrm{M} \mathrm{NaCl}$. For chromatofocusing in the $\mathrm{pH}$ range $7 \cdot 0-4 \cdot 5$, the $\mathrm{PBE} 94$ column was equilibrated with $25 \mathrm{mM}$ imidazole, $\mathrm{pH} 7 \cdot 0$. The bound fraction from the ion exchange chromatography column (containing PME isoforms $B$ and C) was dialysed against the equilibration buffer and applied to the column as described above. Elution of proteins was performed using $10 \%$ (v/v) polybuffer PB74 (Pharmacia), $\mathrm{pH} 4 \cdot 0$. The flow rate was adjusted to $0.25 \mathrm{ml} \mathrm{min}^{-1}$. Fractions of $2 \mathrm{ml}$ were collected. Chromatofocusing was carried out at $4^{\circ} \mathrm{C}$.

The $\mathrm{pH}$ gradient was monitored using a type 405-S7 $\mathrm{pH}$ electrode (Ingold), and the $A_{280}$ of each fraction was determined. Prior to determination of PME activity, each fraction was dialysed overnight against $5 \mathrm{mM}$ PIPES buffer, $\mathrm{pH} 7 \cdot 0$, containing $150 \mathrm{mM} \mathrm{NaCl}$.

Localization of PL. To obtain extracellular proteins, polyethylene membranes with adhering 24-h-old differentiated infection structures were inverted and floated on $350 \mathrm{ml} 50 \mathrm{mM}$ piperazine $/ \mathrm{HCl}$ buffer, $\mathrm{pH} 6.0$ for $10 \mathrm{~min}$. The washing fluid from 15 membranes was adjusted to contain $0.5 \mathrm{M} \mathrm{NaCl}$, cleared by filtration ( $\mathrm{MN} 615$ filter paper, Macherey-Nagel), and concentrated to approximately $7 \mathrm{ml}$ by ultrafiltration using an Amicon 8200 cell with an Amicon YM5 filter $(62 \mathrm{~mm})$ at 2.5 bar pressure.

The washed infection structures were homogenized in $50 \mathrm{mM}$ piperazine/ $\mathrm{HCl}$ buffer, $\mathrm{pH} 6.0$, containing $0 \cdot 1 \%(\mathrm{v} / \mathrm{v})$ Triton $\mathrm{X}-100$ and $0.5 \mathrm{M} \mathrm{NaCl}$ as described above. After centrifugation $\left(45000 \mathrm{~g}, 20 \mathrm{~min}, 2^{\circ} \mathrm{C}\right)$, the pellet was washed with the same buffer and centrifuged again. The supernatants, referred to as intracellular proteins, were combined and concentrated by ultrafiltration as described above.

After dialysis against 500 vols distilled $\mathrm{H}_{2} \mathrm{O}$ overnight at $4{ }^{\circ} \mathrm{C}$, extracellular washing fluid and intracellular proteins were centrifuged as described above and used for PL assay and protein determination. To estimate the fraction of damaged infection structures, the activity of the cytoplasmic marker enzyme NADH-malate dehydrogenase (EC 1.1.1.37) was measured. The optimized assay for fungal malate dehydrogenase consisted of $0.15 \mathrm{mM}$ NADH and $2.5 \mathrm{mM}$ oxaloacetate in $200 \mathrm{mM}$ potassium phosphate buffer, $\mathrm{pH} 9 \cdot 0$. The assay was performed at $30^{\circ} \mathrm{C}$ and the decrease in $A_{340}$ was used as a measure of enzyme activity.

Changes in the apoplastic pH and electrical conductivity of $\boldsymbol{V}$. faba leaves after rust infection. Fourteen-day-old $V$. faba plants were inoculated by spraying with a uredospore suspension [approx. $0.65 \mathrm{mg}$ uredospores and $0.05 \mathrm{mg} \mathrm{BSA}(\mathrm{ml}$ $\left.\mathrm{H}_{2} \mathrm{O}\right)^{-1}$ ] and $8 \mathrm{~d}$ after inoculation heavily infected and uninfected control leaves were excised and washed twice in distilled $\mathrm{H}_{2} \mathrm{O}$ at $0-2{ }^{\circ} \mathrm{C}$. The leaves were infiltrated with distilled $\mathrm{H}_{2} \mathrm{O}$ at $0-2{ }^{\circ} \mathrm{C}$ at $-800 \mathrm{mbar}$ for $3 \mathrm{~min}$, and the vacuum was slowly released over $3 \mathrm{~min}$. The plant material was then blotted dry between paper towels and centrifuged at low speed $(36 \mathrm{~g}$, $20 \mathrm{~min}, 4^{\circ} \mathrm{C}$ ). The intercellular washing fluid (IWF) obtained was used to measure the apoplastic $\mathrm{pH}$, electrical conductivity and extracellular malate dehydrogenase activity.

Vacuum-infiltration of the leaves was repeated with $50 \mathrm{mM}$ $\mathrm{NaCl}$ followed by low speed centrifugation. The leaves were then ground under liquid nitrogen with a pestle and mortar, $1.5 \mathrm{ml} 50 \mathrm{mM} \mathrm{NaCl}$ (g leaf fresh wt) ${ }^{-1}$ added and the suspension stirred for $30 \mathrm{~min}$ at $4{ }^{\circ} \mathrm{C}$. After centrifugation $(45000 \mathrm{~g}, 20 \mathrm{~min}$, $2{ }^{\circ} \mathrm{C}$ ), the leaf extract was used to determine intracellular $\mathrm{pH}$ and malate dehydrogenase activity.

The assay mixture used to measure plant malate dehydrogenase activity contained $0.15 \mathrm{mM}$ NADH and $2.5 \mathrm{mM}$ oxaloacetate in $50 \mathrm{mM}$ potassium phosphate buffer, $\mathrm{pH} 7 \cdot 0$. The assay was performed at $30^{\circ} \mathrm{C}$, and the decrease in $A_{\mathbf{3 4 0}}$ was used as a measure of enzyme activity.

To determine the intracellular $\mathrm{pH}$ of rust infection structures, 24-h-old differentiated structures were homogenized in distilled $\mathrm{H}_{2} \mathrm{O}$ as described above.

To measure the ion activity of the apoplast, $1.5 \mathrm{ml}$ IWF was added to $13.5 \mathrm{ml}$ distilled $\mathrm{H}_{2} \mathrm{O}$ and the conductivity of this solution measured with a conductivity meter (WTW).

Protein determination. Protein concentration was determined in $50 \mathrm{mM} \mathrm{NaOH}$ using a commercially available protein assay kit (Bio-Rad) and a method based on that described by Bradford (1976). $\gamma$-Globulin served as the standard.

\section{RESULTS}

\section{Characterization of PME isoforms}

In fully differentiated 24-h-old infection structures of $U$. viciae-fabae, pre-fractionation of crude extracts by ion exchange chromatography followed by chromatofocusing revealed the presence of four PME isoforms (Fig. 1). The pIs were 8.2 (isoform A) (Fig. 1a), 5.6 (B1) and $5 \cdot 2$ (B2) (Fig. 1b) and 4.5 (C). Use of PBE94 as the gel matrix and polybuffer 74 instead of a DEAE Si 500 column, and the 


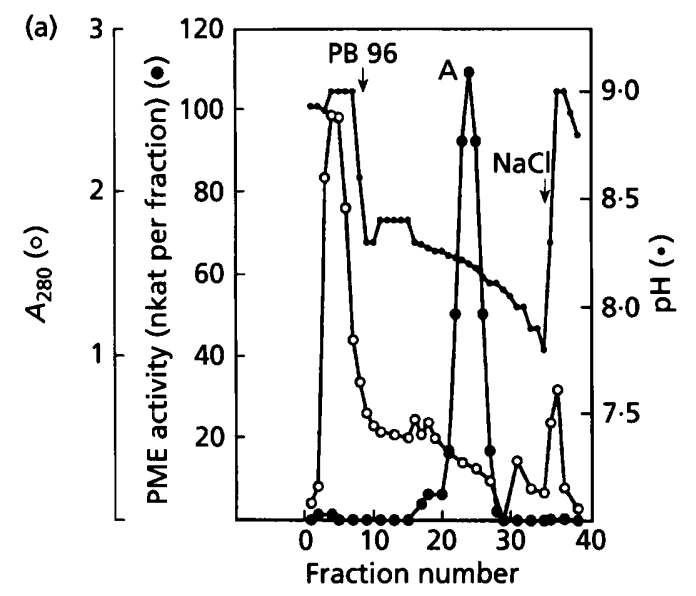

(b)



Fig. 1. Separation of $U$. viciae-fabae PME isoforms A, B1, B2 and $C$ by chromatofocusing. Proteins extracted from 24-h-old differentiated uredosporelings were loaded onto a PBE94 ion exchanger and a one-step-gradient was used to separate isoforms A, B and C. These were subsequently chromatofocused on a PBE94 exchanger using a pH gradient of 9.0-7.0 for isoform $A$ (a) and 7.0-4.5 for isoforms B1, B2 and C (b). Arrows indicate times at which $\mathrm{NaCl}$ and polybuffers PB 96 (a) or PB 74 (b) were added. Representative results are shown.

carrier ampholyte Servalyt 3-8 (Frittrang et al., 1992) allowed resolution of PME isoform B (originally described by Frittrang et al., 1992) into two isoforms, designated $\mathrm{B} 1$ and $\mathrm{B} 2$. The activities of isoform $\mathrm{B} 1$ and $\mathrm{B} 2$ were each found to be $49 \%$ of the total recovered activity applied to the chromatofocusing column in the $\mathrm{pH}$ range $7 \cdot 0-4 \cdot 5$. The remainder was due to isoform $C$ which generally contributed approximately $2-5 \%$ of the activity applied to the column. Chromatofocusing was also used on a preparative scale to yield sufficient enzyme to determine substrate specificity and the $K_{\mathrm{m}}$ values of PME isoforms $\mathrm{A}, \mathrm{B} 1$ and $\mathrm{B} 2$. Isoform $\mathrm{C}$, due to its low activity, was not further studied.

With pectins of different degrees of methylation, PME isoforms A, B1 and B2 exhibited significant differences in substrate specificity (Fig. 2). All isoforms showed very low activity with pectin $\mathrm{N}$ (degree of esterification $8 \%$ ).

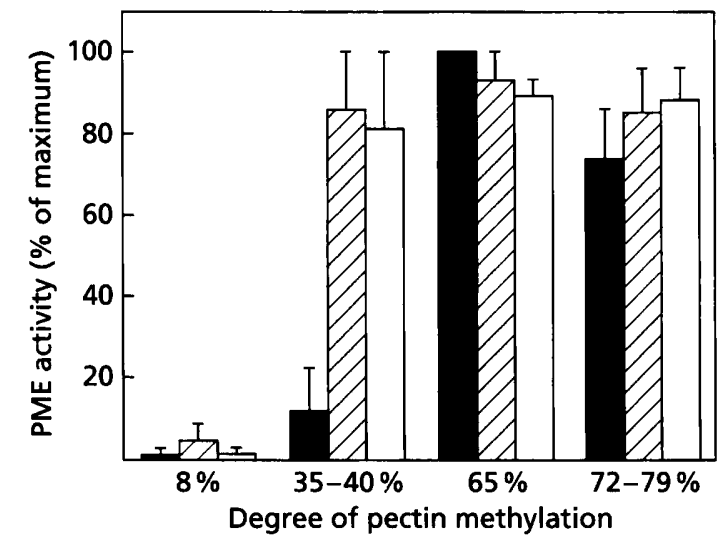

Fig. 2. Effect of the degree of pectin methylation on $P M E$ activity of $U$. viciae-fabae. PME isoforms A ( $\square), B 1(Z)$ and B2 ( $\square$ ) were assayed in the presence of pectin type $N$ (degree of esterification $\sim 8 \%$ ), and apple pectins type $A 1$ (35-40\%), type A2 $(\sim 65 \%)$ and $B(72-79 \%)$. Means of three independent experiments are shown and bars represent SE.

At a degree of esterification of 35-40\%, isoforms B1 and B2 reached approximately $80 \%$ of their maximum activity while isoform A showed only about $10 \%$ maximum activity. At $65 \%$ methylation of the substrate, all isoforms tested exhibited maximum activity.

To determine the dependence of the activities of the PME isoforms on substrate concentration, increasing concentrations of pectin B (degree of esterification $72-79 \%$ ) were used in the enzyme assay (Fig. 3). Isoforms B1 and B2 were both highly active in the presence of low pectin concentrations, whereas isoform A required high substrate concentrations for maximum activity. The $K_{\mathrm{m}}$ values as determined by Eadie-Hofstee transformation of the kinetics data (Fig. 3, insert) showed significantly higher substrate affinity of isoforms B $\left(K_{\mathrm{m}} \mathrm{s} 2.32 \pm 0.66\right.$ and $2.05 \pm 0.77 \mathrm{mg} \mathrm{ml}^{-1}$ for $\mathrm{B} 1$ and $\mathrm{B} 2$, respectively), as compared to isoform $\mathrm{A}\left(K_{\mathrm{m}} 23 \cdot 42 \pm 10 \cdot 1 \mathrm{mg} \mathrm{ml}^{-1}\right)$.

\section{Differentiation-specific PME formation}

The kinetics of the expression of PME were followed during differentiation of $U$. viciae-fabae infection structures for $24 \mathrm{~h}$. PME activity was first detected at $8 \mathrm{~h}$ p.i. on inductive substrates, i.e. when substomatal vesicles were beginning to form (Fig. 4). From 10 to $12 \mathrm{~h}$ p.i. isoforms $\mathrm{A}, \mathrm{B} 1$ and B2 increased dramatically. From $12 \mathrm{~h}$ p.i., isoforms $B$ remained unaltered while isoform $A$ increased until $20 \mathrm{~h}$ p.i. and remained at that level for the next $4 \mathrm{~h}$. Isoform $C$ contributed $2-5 \%$ of total activity. Isoforms $B$ accounted for the majority of PME activity when the substomatal vesicles were differentiated (data not shown) but their relative activities decreased during further development. In contrast, from vesicle to haustorial mother cell differentiation, isoform A increased from approximately 25 to more than $70 \%$ of total activity, as measured in the presence of $10 \mathrm{mg}$ pectin $\mathrm{ml}^{-1}$ in the 


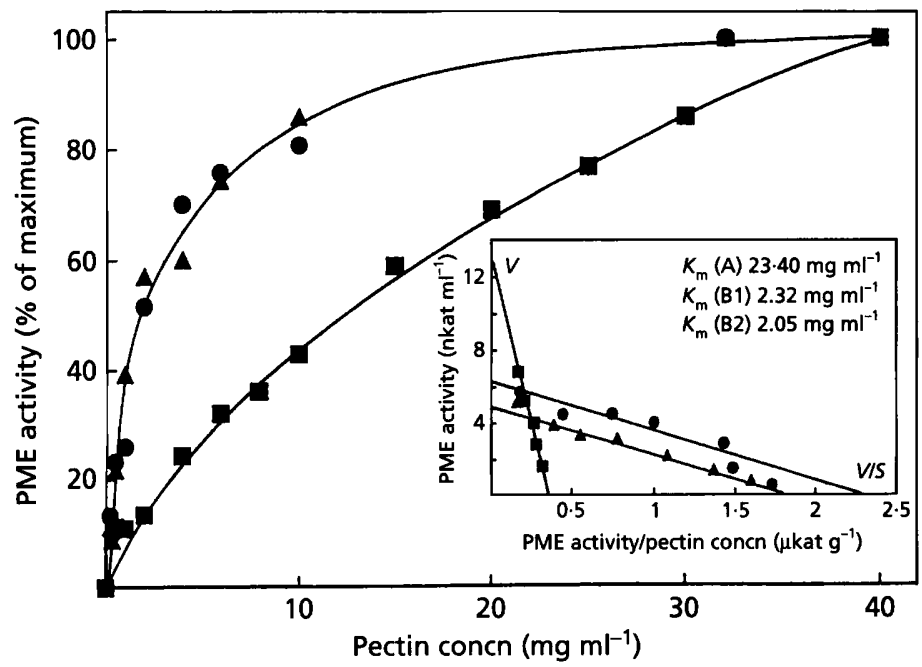

Fig. 3. Effect of substrate concentration on the activity of $U$. viciae-fabae PME isoforms and determination of $K_{m}$ values. Isoforms $A$ $(\square)$, B1 (O) and B2 ( $(A)$ were separated by chromatofocusing and assayed in the presence of different concentrations of pectin type $B$ (degree of esterification 72-79\%). Eadie-Hofstee transformations were used to determine $K_{\mathrm{m}}$ values of the individual isoforms (insert). Means of three independent experiments are shown.

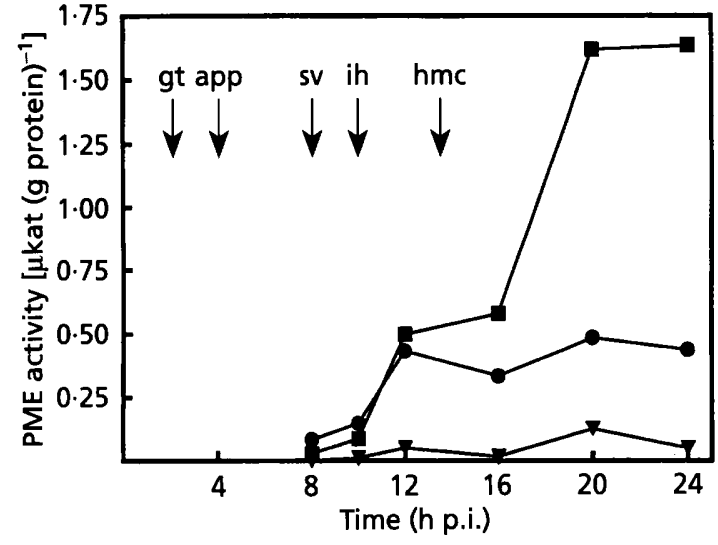

Fig. 4. Kinetics of formation of PME activity in differentiating uredosporelings of $U$. viciae-fabae. The activities of the separated PME isoforms A ( $), B 1+B 2(\bullet)$ and $C(\nabla)$ were determined using pectin type $B$ (degree of esterification $72-79 \%)$. Arrows indicate the occurrence of fungal structures. gt, germ tube; app, appressorium; sv, substomatal vesicle; ih, infection hypha; hmc, haustorial mother cell. Representative results are shown.

reaction mixture. Interestingly, PME was formed in the absence of potential inducers such as pectin or polygalacturonic acid since none of these substances had been added to differentiating infection structures.

\section{Characterization of PL induction}

When uredospores sprayed with sterile distilled $\mathrm{H}_{2} \mathrm{O}$ differentiated to form infection structures, no PL activity was detected during the time frame covered by the experiment (Fig. 5). However, when a polygalacturonate solution was sprayed onto inductive surfaces inoculated with uredospores, PL activity became detectable $14 \mathrm{~h}$ p.i. and increased up to $24 \mathrm{~h}$ p.i. When polygalacturonate was applied $8 \mathrm{~h}$ p.i. to morphogenetic stages that, under

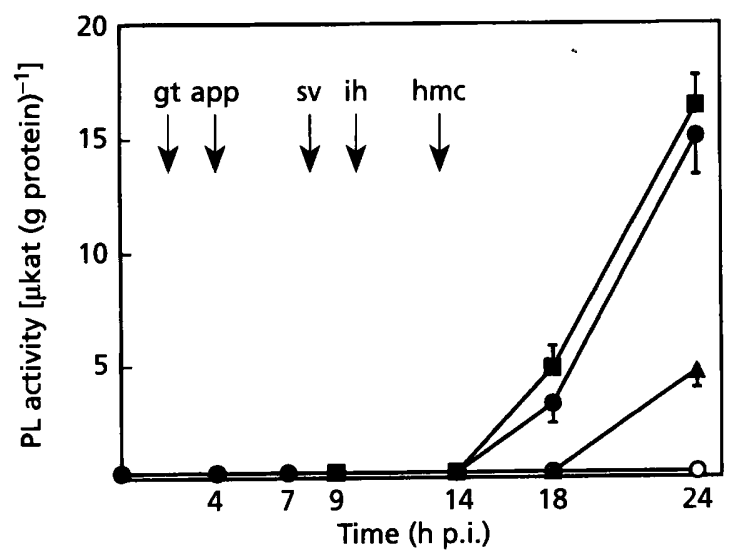

Fig. 5. Kinetics of formation of PL activity in differentiating uredosporelings of $U$. viciae-fabae. Sterile polygalacturonate solution $\left(1 \mathrm{mg} \mathrm{ml}^{-1}\right)$ was applied $0(\square), 8(O)$ or $18(\Delta)$ h p.i.; distilled $\mathrm{H}_{2} \mathrm{O}(\mathrm{O})$ was sprayed onto inoculated membranes $\mathrm{Oh}$ p.i. as a control. Arrows indicate the occurrence of fungal structures (abbreviations as in Fig. 4). The experiment was done in triplicate and bars represent SE.

natural conditions contact pectic substances of the plant mesophyll, the induction kinetics measured were almost identical. Polygalacturonate applied to 18-h-old differentiating structures resulted in significant PL activity after $6 \mathrm{~h}$. It thus appears that the single PL isoform observed in U. viciae-fabae can be induced only in infection hyphae or haustorial mother cells.

The dependence of induction of PL activity on the polygalacturonate concentration applied to uredospores on inductive membranes is shown in Fig. 6. PL activity was induced by polygalacturonate concentrations lower than $0.025 \mathrm{mg} \mathrm{ml}^{-1}$, and at approximately $0.125 \mathrm{mg} \mathrm{ml}^{-1}$ the induction process appeared to be saturated with substrate.

Approximately $76 \%$ of the PL activity of the rust fungus 


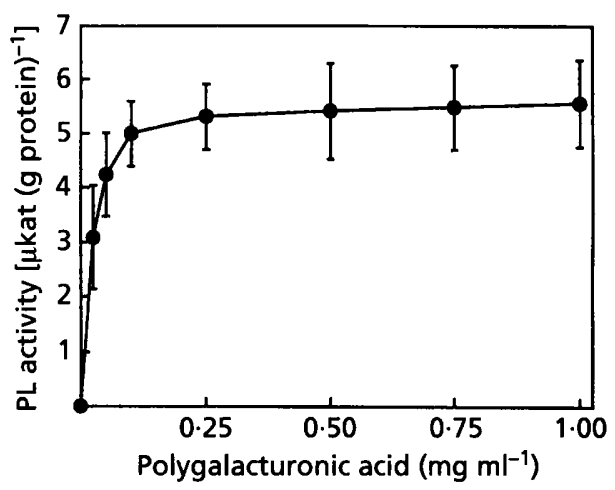

Fig. 6. Effect of polygalacturonate concentration on PL formation in infection structures of $U$. viciae-fabae. Inductive membranes were inoculated with uredospores of the fungus and sprayed with solutions of different substrate concentrations. Infection structures were allowed to differentiate for $24 \mathrm{~h}$. The experiment was carried out four times and bars represent SE.

was found in the extracellular washing fluid (Table 1). The fact that only minor proportions of protein and the cytoplasmic enzyme malate dehydrogenase were detected extracellularly shows that the extracellular location of PL is not due to damage of infection structures.

\section{Effect of mono- or disaccharides on enzyme formation}

Different mono- or disaccharides occurring in the plant apoplast were not involved in the regulation of pectic enzymes of the broad bean rust fungus (Fig. 7). While glucose, fructose and sucrose did not significantly affect the development of PME activity, galacturonic acid monomers reduced activity by approximately $50 \%$ (Fig. $7 \mathrm{a})$. The addition of $50 \mathrm{mM}$ glucose, fructose or sucrose to the polygalacturonate solution needed to induce PL activity of $U$. viciae-fabae did not reduce the extractable enzyme activity by more than $50 \%$ (Fig. 7b).

\section{Characterization of the fungal environment}

Since PME and PL exhibit pH optima of 6.5-8.0 (PME; Frittrang et al., 1992) and 10.3 (PL; H. Deising, unpublished data) it was of interest to determine alterations of apoplastic $\mathrm{pH}$ associated with rust infection. Table 2 shows that the $\mathrm{pH}$ in the apoplast of $U$. viciae-fabaeinfected broad bean leaves is significantly higher than in control plants $8 \mathrm{~d}$ p.i., and also that the intracellular $\mathrm{pH}$ of non-buffered homogenates of rust-infected leaves show $\mathrm{pH}$ values approximately 0.6 units above those of noninfected control plants. Homogenates of 24-h-old differentiated infection structures show $\mathrm{pH}$ values of $5 \cdot 44 \pm 0.03$. The small proportion of malate dehydrogenase activity present in the apoplast $[15.75 \pm 0.612$ and $10.68 \pm 3.93 \mathrm{nkat}(\mathrm{g} \text { fresh } \mathrm{wt})^{-1}$ in rust-infected and control leaves, as compared with $76 \cdot 48 \pm 7 \cdot 61$ and $53.90 \pm 1.02 \mu \mathrm{kat}(\mathrm{g} \text { fresh } \mathrm{wt})^{-1}$ in the respective homogenates] demonstrates the integrity of mesophyll cells. However, the electrical conductivity in IWFs of rustinfected leaves is significantly higher than that of healthy control samples.

\section{Exclusion of bacterial contamination}

Microscopic examination showed that no bacterial contaminants were present during the experiments. In addition, the protein biosynthesis inhibitor cycloheximide, which specifically blocks eukaryotic mRNA translation on $80 \mathrm{~S}$ ribosomes, was added to solutions used to spray inoculated membranes. As shown in Fig. 8, PL induction was inhibited in a dose-dependent manner by cycloheximide. Furthermore, inhibitors such as streptomycin sulfate and ampicillin, which block prokaryotic and plastid protein synthesis, and bacterial cell wall synthesis, respectively, inhibited PL formation to only a minor extent.

\section{DISCUSSION}

Cell-wall-degrading enzymes are thought to be important factors in determining the outcome of interactions between plants and plant-pathogenic fungi (Mendgen \& Deising, 1993). However, little is known about the regulation of these enzymes in obligately biotrophic fungi. In previous reports (Frittrang et al., 1992; Heiler et al., 1993) and in this paper we have demonstrated that the broad bean rust fungus forms cell-wall-degrading enzymes mainly during the time when infection hyphae and haustorial mother cells are differentiated. This

Table 1. Localization of $U$. viciae-fabae PL and malate dehydrogenase activity, and of protein in 24-h-old differentiated infection structures

\begin{tabular}{|lccc|}
\hline Location & $\begin{array}{c}\text { PL } \\
\text { (nkat per } \\
\text { membrane) }\end{array}$ & $\begin{array}{c}\text { Malate } \\
\text { dehydrogenase } \\
\text { (pkat per } \\
\text { membrane) }\end{array}$ & $\begin{array}{c}\text { Protein } \\
\text { (mg per } \\
\text { membrane) }\end{array}$ \\
\hline Extracellular & $203 \cdot 3 \pm 16 \cdot 0$ & $2 \cdot 82 \pm 0 \cdot 02$ & $0 \cdot 145 \pm 0 \cdot 036$ \\
Intracellular & $61 \cdot 5 \pm 16 \cdot 7$ & $204 \cdot 7 \pm 46 \cdot 7$ & $1 \cdot 151 \pm 0 \cdot 199$ \\
Percentage & $76 \cdot 8$ & $1 \cdot 4$ & $12 \cdot 6$ \\
extracellular & & & \\
\hline
\end{tabular}


(a)

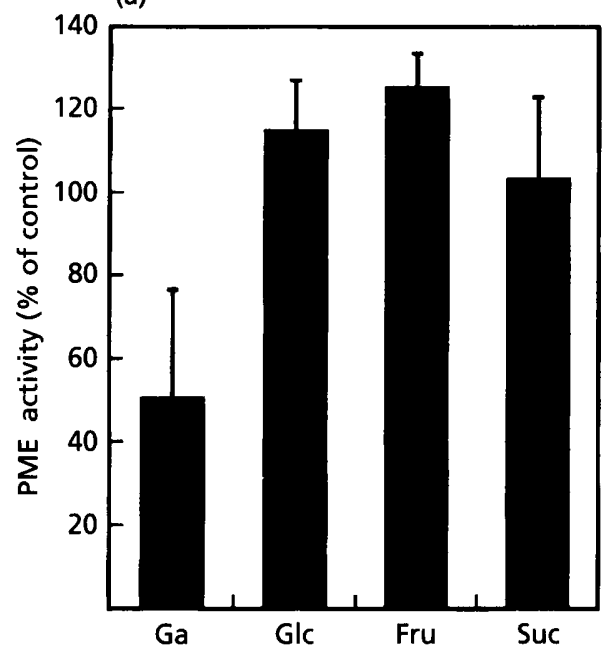

(b)

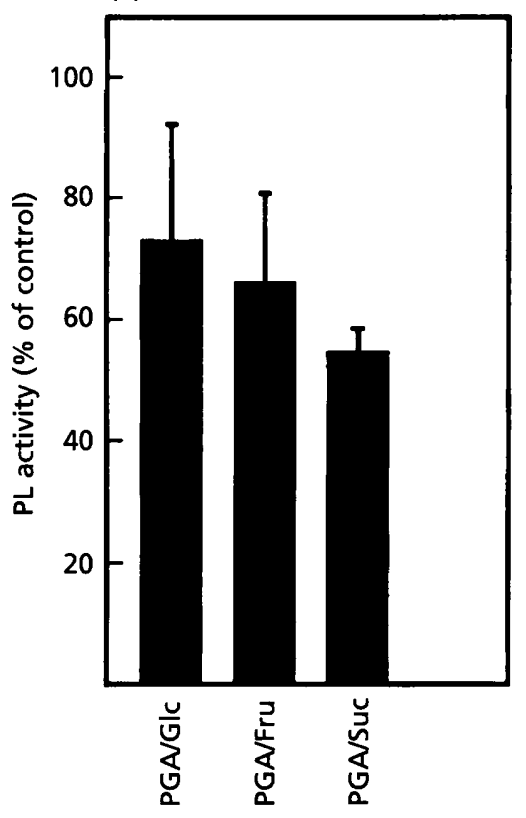

Fig. 7. Effect of different sugars on the formation of PME (a) and $\mathrm{PL}(\mathrm{b})$ in infection structures of $U$. viciae-fabae. Solutions contained $50 \mathrm{mM}$ glucose (GIc), fructose (Fru), sucrose (Suc) or mono-galacturonate (Ga) (a), and $50 \mathrm{mM} \mathrm{Glc}$, Fru or Suc in combination with $0.1 \%$ polygalacturonate (PGA) (b). The sugars were applied to inductive membranes inoculated with uredospores and infection structures were harvested $24 \mathrm{~h}$ p.i. Activities are expressed as a percentage of distilled water (a) or PGA (b) controls. Means of three independent experiments are shown and bars represent SE.

differentiation-specific pattern of enzyme formation may explain why cell-wall-degrading enzymes of rust fungi have been overlooked and why their potential role in the infection process has not been recognized. Heiler et al. (1993) have shown that the broad bean rust fungus produces at least seven cellulolytic enzymes which can be distinguished by their pIs. These enzymes are regulated in a differentiation-specific manner, i.e. their synthesis requires fungal morphogenesis but not the presence of substrate, and is not subject to catabolite repression. The acidic cellulases start to appear during appressorium development (Heiler et al., 1993), while the formation of PME isoforms B1 and B2 (pIs 5.2 and 5.6) begins with differentiation of young infection hyphae, which are usually enlarged to substomatal vesicles (Mendgen \& Deising, 1993; Fig. 4). Under the $\mathrm{pH}$ conditions of the broad bean leaf apoplast (approx. $\mathrm{pH} \mathrm{4.5;} \mathrm{Aloni} \mathrm{et} \mathrm{al.,}$ 1988), even these acidic enzymes would be bound to the plant cell wall. Comparison of the $K_{\mathrm{m}} \mathrm{s}$ of the PMEs of $U$. viciae-fabae reveals that isoforms $\mathrm{B} 1$ and $\mathrm{B} 2$ have an approximately tenfold higher affinity for their substrate than isoform A (Fig. 3, insert). Similar $K_{\mathrm{m}}$ values have been reported for PMEs from Botrytis cinerea (Marcus \& Scheijter, 1983). Isoforms B1 and B2 also act on pectins of low degrees of methylation much more efficiently than isoform A (Fig. 2). Based on their $K_{\mathrm{m}}$ values, the rust PME isoenzymes B1 and B2 could therefore efficiently de-esterify pectins with low degrees of methylation.

Immunocytochemical studies have shown that the polygalacturonate strands are not uniformly esterified across the cell wall. Whereas high degrees of methylation are found in cell wall layers facing the plasmalemma, low degrees of methylation have been demonstrated at the apoplastic side of the cell wall (Liners \& Van Cutsem, 1991). The polygalacturonate strands de-esterified by PME isoforms B1 and B2 should be a good substrate for PL which is formed when haustorial mother cells are differentiated and the penetration process is initiated. PL is induced at a polygalacturonate concentration less than $0.025 \mathrm{mg} \mathrm{ml}^{-1}$ (Fig. 6), and the half maximal reaction velocity of the affinity-purified enzyme has been measured at a polygalacturonate concentration of $0 \cdot 160 \mathrm{mg} \mathrm{ml}^{-1}(\mathrm{H}$. Deising, unpublished data). The low substrate concentration required for PL induction, the low $K_{\mathrm{m}}$, the high percentage (approx. 76\%) in an extracellular location (Table 1) and the high pI of the enzyme should result in efficient and localized degradation of the pectic layers of the host cell wall. These results provide an alternative explanation for the speculations (Keon et al., 1987) that cell-wall-degrading enzymes of obligate biotrophs might be bound to the fungal cell wall in order to minimize tissue damage. Since U. viciae-fabae PL requires highly de-esterified substrates (35\% methylation results in $90 \%$ reduction of PL activity; $\mathrm{H}$. Deising, unpublished data), PME is likely to play an important role in the preparation of the infection court. The mobility of wall-degrading enzymes, however, can be regarded as critical for the degree of tissue damage (Kotoujansky, 1987; Benhamou et al., 1991). As deduced from its extreme $\mathrm{pI}(\geqslant 10 \cdot 5)$, the PL should be tightly bound to the negatively charged plant cell wall at the site of its secretion. At late stages of infection structure development, i.e. when infection hyphae and haustorial mother cells are formed, the neutral endocellulases (pIs 7.1 and 7.3; Heiler et al., 1993) and the basic PME isoform A (pI 8.2; Frittrang et al., 1992) are present and these enzymes, like PL, should be tightly bound to the plant cell wall at the site of penetration. For localized wall degradation, both a tight binding and a $\mathrm{pH}$ 
Table 2. Effect of $U$. viciae-fabae infection on apparent apoplastic and intracellular $\mathrm{pH}$ $\left(\mathrm{pH}_{\mathrm{app}}\right)$, and on cell integrity (measured as percentage extracellular malate dehydrogenase activity and electrical conductivity) of $V$. faba leaves

\begin{tabular}{|c|c|c|c|c|}
\hline$V \cdot f a b a$ tissue & $\begin{array}{c}\text { Apoplastic } \\
\text { pH }_{\text {app }}\end{array}$ & $\begin{array}{c}\text { Intracellular } \\
\mathrm{pH}_{\mathrm{app}}\end{array}$ & $\begin{array}{c}\text { Extracellular } \\
\text { malate } \\
\text { dehydrogenase } \\
\text { activity }(\%)\end{array}$ & $\begin{array}{c}\text { Electrical } \\
\text { conductivity } \\
\text { in IWF } \\
\left(\mu \mathrm{S} \mathrm{cm} \mathrm{cm}^{-1}\right)\end{array}$ \\
\hline U. viciae-fabae-infected leaves & $6 \cdot 69 \pm 0 \cdot 10$ & $5.63 \pm 0.06$ & $0.021 \pm 0 \cdot 002$ & $15 \cdot 1 \pm 0 \cdot 1$ \\
\hline Non-infected leaves & $6 \cdot 31 \pm 0 \cdot 11$ & $5 \cdot 08 \pm 0 \cdot 04$ & $0 \cdot 020 \pm 0 \cdot 001$ & $10 \cdot 1 \pm 0 \cdot 6$ \\
\hline
\end{tabular}

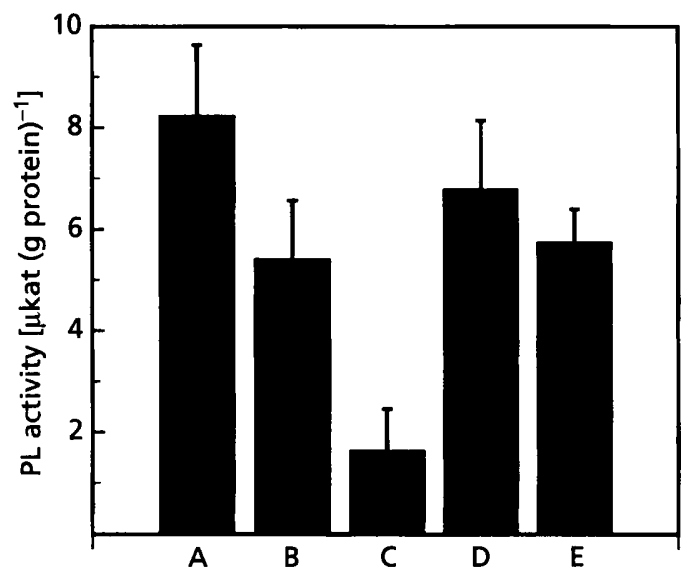

Fig. 8. Effect of cycloheximide, streptomycin sulfate or ampicillin on formation of PL activity of $U$. viciae-fabae. Inductive membranes inoculated with uredospores were sprayed with $0.1 \%$ polygalacturonate alone (control, A), or in combination with streptomycin sulfate (E) or ampicillin (D) $\left(0.5 \mathrm{mg} \mathrm{ml}^{-1}\right.$ each). Cycloheximide $\left[0.1\right.$ (B) or 10 (C) $\mu \mathrm{g} \mathrm{ml}^{-1}$ ] was applied $8 \mathrm{~h}$ after application of polygalacturonate. Differentiated structures were harvested $24 \mathrm{~h}$ p.i. Means of three independent experiments are shown and bars represent SE.

shift towards alkaline conditions would be important. Alkalinization of the medium would activate the enzymes in the order of their $\mathrm{pH}$ optima. A number of studies have shown that fungi growing on polygalacturonate, but not on non-pectic carbon sources such as cellulose, shift the $\mathrm{pH}$ of the medium towards an alkaline $\mathrm{pH}$ (Hancock, 1966; Wijesundera et al., 1989; Bugbee, 1990). On artificial membranes however, the $\mathrm{pH}$ of the pectate solution used to spray uredospores or infection structures was not altered during the experiment, i.e. for $24 \mathrm{~h}$ (unpublished data).

In barley leaves infected with brown rust (Puccinia bordei), the $\mathrm{pH}$ of the apoplastic sap increased from 6.6 in controls to 7.3 in diseased leaves (Tetlow \& Farrar, 1993). In rustinfected broad bean leaves, the $\mathrm{pH}$ had increased from 6.3 to 6.7 by $8 \mathrm{~d}$ after inoculation (Table 2). The method used to determine apoplastic $\mathrm{pH}$ alterations, i.e. infiltration of the leaf with distilled $\mathrm{H}_{2} \mathrm{O}$ followed by low speed centrifugation to collect IWF, may be criticized since localized changes which may occur in small areas around the haustorial mother cell cannot be detected. Because of this it is probable that more pronounced and highly localized increases in $\mathrm{pH}$ occur in restricted cell wall areas of the $V$. faba mesophyll. Since $\mathrm{pH}$ values increased by more than 0.6 units have also been found in homogenates of infected leaves, and since rust infection structures show intracellular $\mathrm{pH}$ values around 5.4, it appears that the host plant rather than the fungus is responsible for the increase in the apoplastic $\mathrm{pH}$. Low extracellular malate dehydrogenase activity demonstrates cell integrity, but it is possible that losses of $\mathrm{OH}^{-}$ions could occur locally. The increased electrical conductivity found in IWF from rustinfected leaves supports this hypothesis. One might assume that a shift in $\mathrm{pH}$ to 9 or higher could activate the $\mathrm{PL}$ of the fungus. It may also result in the release of cellulases and PMEs from the cell wall exchangers. At sites where the highly methylated pectin at the inner side of the primary wall (Liners \& Van Cutsem, 1991) would not be completely de-esterified by PME, wall degradation by PL would be restricted, due to remaining methyl groups esterified to the substrate. The interplay of physico-chemical properties of the pectic enzymes resulting in tight binding to the plant cell wall, and their requirements for $\mathrm{pH}$ and substrate properties may be the physico- and biochemical basis for limited tissue degradation by obligate biotrophs.

Other reports on pectic enzymes from biotrophs or hemibiotrophs, for example Bremia lactucae (Van PeltHeerschap \& Smit-Bakker, 1993) and Venturia inaequalis (Valsangiacomo \& Gessler, 1992) have been published recently. The only pectate-degrading enzyme produced by $V$. inaequalis is an exopolygalacturonase. An exocleaving mode could prevent the formation of elicitoractive pectin fragments (Nothnagel et al., 1983; Bishop et al., 1984; Bruce \& West, 1989; Mathieu et al., 1991; Tenhaken \& Barz, 1991) and possibly the induction of plant defence mechanisms. The fact that polygalacturonase, which is thought to be highly destructive, is formed not only by necrotrophs but also by obligate biotrophs such as B. lactucae (Van Pelt-Heerschap \& SmitBakker, 1993) and Puccinia graminis f. sp. tritici (Van Sumere et al., 1957) is not in conflict with the requirements of the concept of minimal tissue damage needed for, and typically observed in, interactions involving biotrophs, 
since polygalacturonases are known which do not cause maceration of plant tissue (McClendon, 1979). The fact that some biotrophs or hemi-biotrophs form either lyases or hydrolases to degrade polygalacturonate may result from adaptation to the chemical composition of the cell walls of their host plant. An enzymic adaptation to the monocotyledonous primary cell wall has also been discussed for cereal pathogens such as Rbizoctonia cerealis, Fusarium culmorum, and Pseudocercosporella berpotrichoides (Cooper et al., 1988).

In general, cell-wall-degrading enzymes of plant-pathogenic fungi have been shown to be subject to catabolite repression. For example, Horton \& Keen (1966) demonstrated that the formation of endopolygalacturonase and cellulase of the onion pathogen Pyrenochaeta terrestris is repressed in the presence of $5 \mathrm{mM}$ glucose. Likewise, formation and secretion of a number of cell-wall-degrading enzymes, for example polygalacturonase, pectate lyase, cellulase, $\beta$-glucosidase, $\alpha$-galactosidase and $\beta$ xylosidase of the root-rotting fungus Pyrenochaeta lycopersici are repressed in the presence of $1.4 \mathrm{mM}$ glucose, $1.2 \mathrm{mM}$ fructose, and $0.72 \mathrm{mM}$ inositol (Goodenough et al., 1976). Holz \& Knox-Davies (1986) showed that the concentrations of sugars found in onion apoplasts are sufficient to repress the formation of cell-wall-degrading enzymes in Fusarium oxysporum f. sp. cepae and these authors discuss apoplast sugar concentration as a factor in resistance to the pathogen. This type of regulation has been described not only for hydrolases and lyases, but also for PME of the polyphagous fungus Botrytis cinerea (Reignault et al., 1993), suggesting common regulatory mechanisms. If, however, the formation of cell-walldegrading enzymes of obligate biotrophs such as rust fungi are catabolite repressible by apoplast sugars (Holz \& Knox-Davies, 1986), it is very unlikely that these enzymes are available at the time when the pathogen attempts penetration of the host cell wall. Thus, repression of these enzymes by catabolites would represent a disadvantage to the fungus. Heiler et al. (1993) have shown that cellulase activity of the broad bean rust fungus is not repressed even by glucose, fructose or sucrose concentrations as high as $50 \mathrm{mM}$, but rather appears to be increased. Likewise, the present study on PL and PME has shown that neither enzyme is repressed by the concentrations of these sugars found in broad bean apoplasts. Delrot et al. (1983) report that sucrose, which is the most prominent apoplastic low-molecular-mass sugar in $V$. faba leaves, shows nycthemeral changes from 1 to $4.5 \mathrm{mM}$. Hexoses such as glucose and fructose are present at lower concentrations.

A major concern in the study of pectic enzymes of rust fungi in artificial systems is bacterial contamination of the infection structures. To test possible synthesis of pectic enzymes by bacteria associated with uredospores, inhibitors blocking eukaryotic or prokaryotic protein biosynthesis or bacterial wall synthesis have been used. Similar studies have demonstrated the eukaryotic origin of PME (Frittrang et al., 1992) and cellulases (Heiler et al., 1993), and several lines of evidence indicate that the PL studied in this paper is not due to bacterial contaminants but is produced by the broad bean rust fungus. First, the protein biosynthesis inhibitor cycloheximide blocks formation of the enzyme in a concentration-dependent manner (Fig. 8). Since relatively high cycloheximide concentrations did not completely block enzyme formation, an inhibitor of bacterial cell wall synthesis and an inhibitor of protein synthesis specific for 705 ribosomes were also used. Even at high concentrations of ampicillin and streptomycin sulfate, PL induction was not significantly affected, indicating the eukaryotic origin of the enzyme. In addition, if bacterial contaminants did account for PL synthesis the application of pectate at 0,8 and $18 \mathrm{~h}$ p.i. should result in the onset of enzyme formation at more or less comparable times after application. The pattern observed (Fig. 5) suggests that a combination of morphogenesis and the presence of substrate are required for enzyme synthesis by the rust fungus. Furthermore, low-molecular-mass sugars have been shown to be potent repressors of PL induction in bacteria (Kotoujansky, 1987), whereas in U. viciae-fabae sugar concentrations as high as $50 \mathrm{mM}$ did not result in substantial repression of either PL or PME. Also, the application of polygalacturonic acid to a naturally occuring population of different bacterial species, as would be present on contaminated uredospores, should result in the formation of a mixture of polygalacturonases and PLs rather than a single lyase as observed in differentiated infection structures of $U$. viciaefabae.

In conclusion, the data presented show that the broad bean rust fungus $U$. viciae-fabae produces pectic enzymes during infection structure differentiation. In contrast to saprophytes and highly destructive necrotrophs, the regulation of the quantities of the enzymes produced, the timing of their synthesis and their physico-chemical properties appear to result in limited cell wall degradation and possibly preparation of the infection court. Pressure applied by the haustorial mother cell may then be involved in supporting growth through the enzymically softened plant cell wall and in allowing the fungus to penetrate without disruption of the cell integrity needed for biotrophy.

\section{ACKNOWLEDGEMENTS}

We thank the Deutsche Forschungsgemeinschaft (DFG) for financial support (Me 523/14-2) to H.D. and K.M. We also thank Dr R. L. Nicholson, Purdue University, West Lafayette, IN, USA, and Dr M. Hahn, Dr A. L. Ádám, M. Haug, S. Heiler and $M$. Rauscher, University of Konstanz, for critically reading the manuscript.

\section{REFERENCES}

Aloni, B., Daie, J. \& Wyse, R. E. (1988). Regulation of apoplastic pH in source leaves of Vicia faba by gibberellic acid. Plant Physiol $\mathbf{8 8}$, 367-369.

Benhamou, N., Lafitte, C., Barthe, J.-P. \& Esquerré-Tugayé, M.-T. (1991). Cell surface interactions between bean leaf cells and Colletotrichum lindemuthianum. Cytochemical aspects of pectin breakdown and fungal endopolygalacturonase accumulation. Plant Physiol 97, 234-244. 
Bishop, P. D., Pearce, G., Byrant, J. E. \& Ryan, C. A. (1984). Isolation and characterization of the proteinase inhibitor-inducing factor from tomato leaves. Identity and activity of poly- and oligogalacturonide fragments. $J$ Biol Chem 259, 13172-13177.

Bradford, M. M. (1976). A rapid and sensitive method for the quantitation of microgram quantities of protein utilizing the principle of protein dye binding. Anal Biochem 72, 248-254.

Bruce, R. J. \& West, C. A. (1989). Elicitation of lignin biosynthesis and isoperoxidase activity by pectic fragments in suspension cultures of castor bean. Plant Pbysiol 91, 889-897.

Bugbee, W. M. (1990). Purification and characterization of pectin lyase from Rhizoctonia solani. Physiol Mol Plant Patbol 36, 15-25.

Cooper, R. M. (1983). The mechanism and significance of enzymic degradation of host cell walls by parasites. In Biochemical Plant Pathology, pp. 101-135. Edited by J. A. Callow. NY: John Wiley.

Cooper, R. M. (1984). The role of cell wall-degrading enzymes in infection and damage. In Plant Diseases: Infection, Damage and Loss, pp. 13-27. Edited by R. K.S. Wood \& G. J. Jellis. Oxford: Blackwell Scientific Publications.

Cooper, R. M. \& Durrands, R. K. (1989). Selection, characterization, pathogenicity and virulence of pectinase-deficient mutants of Verticillium albo-atrum. In Vascular Wilt Diseases of Plants, pp. 325-335. Edited by E. C. Tjamos \& C. Beckman. Berlin: SpringerVerlag.

Cooper, R. M., Longman, D., Campbell, A., Henry, M. \& Lees, P. E. (1988). Enzymic adaptation of cereal pathogens to the monocotyledonous primary wall. Physiol Mol Plant Patbol 32, 33-47.

Cotty, P. J., Cleveland, T. E., Brown, R. L. \& Mellon, J. E. (1990). Variation in polygalacturonase production among Aspergillus flavus isolates. Appl Environ Microbiol 56, 3885-3887.

Crawford, M. S. \& Kolattukudy, P. E. (1987). Pectate lyase from Fusarium solani $\mathrm{f}$. sp. pisi: purification, characterization, in vitro translation of the mRNA, and involvement in pathogenicity. Arch Biocbem Biophys 258, 196-205.

Dean, R. A. \& Timberlake, W. E. (1989). Production of cell walldegrading enzymes by Aspergillus nidulans: a model system for fungal pathogenesis of plants. Plant Cell 1, 265-273.

Deising, H., Jungblut, P. R. \& Mendgen, K. (1991). Differentiationrelated proteins of the broad bean rust fungus Uromyces viciae-fabae, as revealed by high resolution two-dimensional polyacrylamide gel electrophoresis. Arch Microbiol 155, 191-198.

Delrot, S., Faucher, M., Bonnemain, J.-L. \& Bonmort, J. (1983). Nycthemeral changes in intracellular and apoplastic sugars in Vicia faba leaves. Pbysiol Veg 21, 459-467.

Frittrang, A. K., Deising, H. \& Mendgen, K. (1992). Characterization and partial purification of pectinesterase, a differentiationspecific enzyme of Uromyces viciae-fabae. J Gen Microbiol 138, 2213-2218.

Goodenough, P. W., Kempton, R. J. \& Maw, G. A. (1976). Studies on the root rotting fungus Pyrenocbaeta lycopersici: extracellular enzyme secretion by the fungus grown on cell-wall material from susceptible and tolerant tomato plants. Physiol Plant Pathol 8, 243-251.

Hancock, J. G. (1966). Pectate lyase production by Colletotrichum trifolii in relation to changes in $\mathrm{pH}$. Phytopathol 56, 1112-1113.

Heiler, S., Mendgen, K. \& Deising, H. (1993). Cellulolytic enzymes of the obligately biotrophic rust fungus Uromyces viciae-fabae are regulated differentiation-specifically. Mycol Res 97, 77-85.

Holz, G. \& Knox-Davies, P. S. (1986). Possible involvement of apoplast sugars in endo-pectin-transeliminase synthesis in onion bulb rot caused by Fusarium oxysporum f. sp. cepae. Physiol Mol Plant Pathol 28, 403-410.
Horton, J. C. \& Keen, N. T. (1966). Sugar repression of endopolygalacturonase and cellulase synthesis during pathogenesis by Pyrenochaeta terrestris as a resistance mechanism in onion pink root. Phytopatbol 56, 908-916.

Howell, C. R. (1976). Use of enzyme deficient mutants of Verticillium dabliae to assess the importance of pectolytic enzymes in symptoms of Verticillium wilt of cotton. Physiol Plant Pathol 9, 279-283.

Keen, N. T. \& Erwin, D. C. (1971). Endopolygalacturonase: evidence against involvement in Verticillium wilt in cotton. Pbytopatbology 61, 198-203.

Keon, J. P. R., Byrde, R. J. W. \& Cooper, R. M. (1987). Some aspects of fungal enzymes that degrade plant cell walls. In Fungal Infection of Plants. Symposium of the British Mycological Society, pp. 133-157. Edited by G. F. Pegg \& P. G. Ayres. Cambridge: Cambridge University Press

Köller, W., Allan, C. R. \& Kolattukudy, P. E. (1982). Role of cutinase and cell wall degrading enzymes in infection of Pisum sativum by Fusarium solani f. sp. pisi. Physiol Plant Patbol 20, 47-60.

Kotoujansky, A. (1987). Molecular genetics of pathogenesis by soft-rot erwinias. Annu Rev Phytopathol 25, 405-430.

Liners, F. \& Van Cutsem, P. (1991). Immunocytochemical localization of homopolygalacturonic acid on plant cell walls. Micron Microsc Acta 22, 265-266.

McClendon, J. H. (1979). Subterminal polygalacturonase, a nonmacerating enzyme, attacks pectate from the reducing end. Plant Pbysiol 63, 74-78.

Marcus, L. \& Scheijter, A. (1983). Single step chromatographic purification and characterization of the endopolygalacturonases and pectinesterases of the fungus Botrytis cinerea Pers. Physiol Plant Patbol 22, 1-13.

Mathieu, Y., Kurkdjian, A., Xia, H., Guern, J., Koller, A., Spiro, M. D., O'Neill, M., Albersheim, P. \& Darville, A. (1991). Membrane responses induced by oligogalacturonides in suspension-cultured tobacco cells. Plant J 1, 333-343.

Melgarejo, P., Carrillo, R. \& Sagasta, E. M. (1985). Mycoflora of peach twigs and flowers and its possible significance in biological control of Monilinia laxa. Trans Br Mycol Soc 85, 313-317.

Mendgen, K. \& Deising, H. (1993). Infection structures of fungal plant pathogens - a cytological and physiological evaluation. New Pbytol 124, 193-213.

Nothnagel, E. A., McNeil, M., Albersheim, P. \& Dell, A. (1983). Host parasite interactions XXII. A galacturonic acid oligosaccharide from plant cell walls elicits phytoalexins. Plant Pbysiol 71, 916-926.

Reignault, P., Boccara, M., Mercier, M., Lepen, B. \& Bompeix, G. (1993). Purification and characterization of pectinmethyl esterase produced by Botrytis cinerea. Serological comparison with pectinmethylesterase from Erwinia chrysanthemi and Glycine max. In Mechanisms of Plant Defense Responses, pp. 81. Edited by B. Fritig \& M. Legrand. Dordrecht: Kluwer Academic Publishers.

Scott-Craig, J. S., Panaccione, D. G., Cervone, F. \& Walton, J. D. (1990). Endopolygalacturonase is not required for pathogenicity of Cocbliobolus carbonum on maize. Plant Cell 2, 1191-1200.

Tenhaken, R. \& Barz, W. (1991). Characterization of pectic enzymes from the chickpea pathogen Ascocbyta rabiei. $Z$ Naturforsch Sect $C$ Biosci 46, 51-57.

Tetlow, I. J. \& Farrar, J. F. (1993). Apoplastic sugar concentration and $\mathrm{pH}$ in barley leaves infected with brown rust. $J$ Exp Bot 44, 929-936.

Valsangiacomo, C. \& Gessler, C. (1992). Purification and characterization of an exo-polygalacturonase produced by Venturia 
inaequalis, the causal agent of apple scab. Physiol Mol Plant Patbol 40, 63-77.

Van Pelt-Heerschap, H. \& Smit-Bakker, O. (1993). Cell-wall degrading enzymes synthesized by the obligate pathogen Bremia lactucae. In Mechanisms of Plant Defense Responses, pp. 82. Edited by B. Fritig \& M. Legrand. Dordrecht: Kluwer Academic Publishers. Van Sumere, C. F., Van Sumere-De Preter, C. \& Ledingham, G. A. (1957). Cell-wall-splitting enzymes of Puccinia graminis var. tritici. Can J Microbiol 3, 761-770.

Wattad, C., Dinoor, A. \& Prusky, D. (1994). Purification of pectate lyase produced by Colletotrichum gloeosporioides and its inhibition by epicatechin: a possible factor involved in the resistance of unripe avocado fruits to anthracnose. Mol Plant-Microbe Interact 7, 293-297.

Wijesundera, R. L. C., Bailey, J. A., Byrde, R. J. W. \& Fielding, A. H. (1989). Cell wall degrading enzymes of Colletotrichum lindemutbianum: their role in the development of bean anthracnose. Physiol Mol Plant Pathol 34, 403-413.

Received 26 July 1994; revised 19 October 1994; accepted 1 November 1994. 